\title{
Dynamic balance decreased in postdromal migraineurs compared to non migraine controls
}

\author{
MT Moore*, R Feuerherd \\ From The European Headache and Migraine Trust International Congress \\ London, UK. 20-23 September 2012
}

\section{Introduction}

Balance is a complex process involving visual, vestibular and neuromuscular control. Migraineurs often report vertigo and dizziness symptoms during and post migraine. The Biodex Balance System SD 1 is a reliable method to measure dynamic balance. Little research 2 has examined dynamic balance in migraineurs compared to individuals who do not have migraines.

\section{Purpose}

The purpose of this research is to examine the differences between migraineurs and controls dynamic balance at two testing intervals: baseline (migraine free 7 days) and post migraine (within 48 hours of migraine onset).

\section{Methods}

20 controls (C) (age 25.70 \pm 10.77) and 17 Migraineurs (M) (age 25.24 \pm 9.55) completed dual limb support testing on the Biodex Balance System SD. Limits of Stability (LOS) testing at moderate skill level $(75 \%)$ involved center of gravity control within their base of support. The clinical test of sensory integration and balance tested stability and sway indexes within four conditions (eyes open/closed on firm vs foam surface) for 30 second intervals.

\section{Results}

A repeated measures ANOVA revealed significant differences [mean diff (post-pre) $\mathrm{C}=7.06 \pm 5.57, \mathrm{M}=2.68 \pm 7.45$, $\mathrm{p}=.029$ ] between migraineurs and non-migraineurs in overall LOS post migraine. Significant decreases were found between shift of balance to the right [mean diff (post-pre) $\mathrm{C}=14.71 \pm 17.69, \mathrm{M}=-2.18 \pm 16.97, \mathrm{p}=.034]$ and balance to the left [mean diff (post-pre) $\mathrm{C}=9.88 \pm 15.77$, $\mathrm{M}=-3.75 \pm 22.1, \mathrm{p}=.019]$ post migraine. No significant differences were found between groups for overall LOS at

Northern Michigan University, USA baseline $(\mathrm{p}=.703)$. No significant differences were found between groups for stability or sway indexes for all conditions on the clinical test of sensory integration.

\section{Conclusions}

Migraineurs exhibit difficulty with center of gravity shifts to the right and left and overall dynamic LOS post migraine. Once LOS is exceeded a fall, stumble or step will ensue. This suggests decreases in lower extremity strength, proprioception and vestibular deficiencies.

Published: 21 February 2013

\section{References}

1. Cachupe WJ, Shifflett B, Kahanov L, Wughalter EH: Reliability of Biodex Balance System measures. Measurement in Physical Education and Exercise Science 2001, 5:97-108.

2. Ishizaki K, Nozomi M, Takeshima T, Fukuhara Y, ljiri T, Kusumi M, et al: Static stabilometry in patients with migraine and tension-type headache during a headache-free period. Psychiatry and Clinical Neurosciences 2002, 56:85-90.

doi:10.1186/1129-2377-14-S1-P73

Cite this article as: Moore and Feuerherd: Dynamic balance decreased in postdromal migraineurs compared to non migraine controls. The Journal of Headache and Pain 2013 14(Suppl 1):P73.

Submit your manuscript to a SpringerOpen ${ }^{\bullet}$ journal and benefit from:

- Convenient online submission

- Rigorous peer review

- Immediate publication on acceptance

- Open access: articles freely available online

- High visibility within the field

- Retaining the copyright to your article

Submit your next manuscript at $\gg$ springeropen.com

\section{SpringerOpen ${ }^{\circ}$}

( 2013 Moore and Feuerherd; licensee Springer. This is an Open Access article distributed under the terms of the Creative Commons Attribution License (http://creativecommons.org/licenses/by/2.0), which permits unrestricted use, distribution, and reproduction in any medium, provided the original work is properly cited. 